\title{
Lidar Point Density Analysis - Implications for Identifying Water Bodies
}

Scientific Investigations Report 2014-5191

U.S. Department of the Interior U.S. Geological Survey 
Cover. Blackhawk County, lowa. 


\section{Lidar Point Density Analysis_Implications for Identifying Water Bodies}

By Bruce B. Worstell, Sandra K. Poppenga, Gayla A. Evans, and Sandra A. Prince

Scientific Investigations Report 2014-5191 


\title{
U.S. Department of the Interior SALLY JEWELL, Secretary
}

\section{U.S. Geological Survey Suzette M. Kimball, Acting Director}

\author{
U.S. Geological Survey, Reston, Virginia: 2014
}

For more information on the USGS - the Federal source for science about the Earth, its natural and living resources, natural hazards, and the environment, visit http://www.usgs.gov or call 1-888-ASK-USGS.

For an overview of USGS information products, including maps, imagery, and publications, visit http://www.usgs.gov/pubprod

To order this and other USGS information products, visit http://store.usgs.gov

Any use of trade, firm, or product names is for descriptive purposes only and does not imply endorsement by the U.S. Government.

Although this information product, for the most part, is in the public domain, it also may contain copyrighted materials as noted in the text. Permission to reproduce copyrighted items must be secured from the copyright owner.

Suggested citation:

Worstell, B.B., Poppenga, S.K., Evans, G.A., Prince, S.A., 2014, Lidar point density analysis-Implications for identifying water bodies: U.S. Geological Survey Scientific Investigations Report 2014-5191, 19 p., http://dx.doi.org/10.3133/ sir20145191.

ISSN 2328-0328 (online) 


\section{Contents}

Abstract
Introduction.
Study Area.
Data Used in the Analysis
Lidar Point Density Analysis.
Elevation Assignment for Void Regions
Lidar Return Density Variability of Void Regions
Assigning New Elevation Values in Rivers, Lakes, and Ponds
Limitations and Considerations
Acknowledgments
References Cited

\section{Figures}

1. Map showing Cedar River area in Blackhawk County, lowa .............................................3

2. Map showing Clearwater River area in Beltrami County, Minnesota .................................4

3. Maps showing segmentation of lidar returns into regions of voids and nonvoids ...........6

4. Map showing example of artifacts when a single threshold is used to

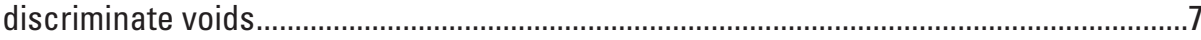

5. Overall data processing flow chart ............................................................................

6. Maps showing moving window analysis of rasterized lidar data for the lowa

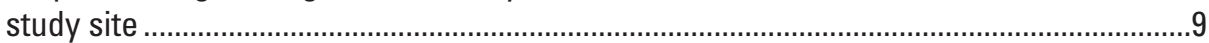

7. Map showing void regions for the Blackhawk County, lowa, site ...................................10

8. Maps showing an example of a simple void region over a water feature........................11

9. Maps showing an example of a void region with interior polygons designated as



10. Maps showing an example void region with an interior island ....................................14

11. Maps showing lowa site comparison of original and modified river channels ...............15

12. Maps showing comparison of the original and the modified river channels located in Beltrami County, Minnesota. 


\section{Conversion Factors and Datums}

\begin{tabular}{lll}
\hline \multicolumn{1}{c}{ Multiply } & By & \multicolumn{1}{c}{ To obtain } \\
\hline & Length & \\
\hline centimeters $(\mathrm{cm})$ & 0.3937 & inches (in.) \\
meters $(\mathrm{m})$ & 3.2808 & foot (ft) \\
kilometers $(\mathrm{km})$ & 0.6215 & miles (mi) \\
\hline & Area & \\
\hline square meter $\left(\mathrm{m}^{2}\right)$ & 10.76 & square foot $\left(\mathrm{ft}^{2}\right)$ \\
\hline
\end{tabular}

Vertical coordinate information is referenced to the North American Vertical Datum of 1988 (NAVD 88).

Horizontal coordinate information is referenced to North American Datum of 1983 (NAD 83).

Elevation, as used in this report, refers to distance above the vertical datum. 


\title{
Lidar Point Density Analysis- Implications for Identifying Water Bodies
}

\author{
By Bruce B. Worstell', Sandra K. Poppenga², Gayla A. Evans², and Sandra A. Prince ${ }^{1}$
}

\section{Abstract}

Most airborne topographic light detection and ranging (lidar) systems operate within the near-infrared spectrum. Laser pulses from these systems frequently are absorbed by water and therefore do not generate reflected returns on water bodies in the resulting void regions within the lidar point cloud. Thus, an analysis of lidar voids has implications for identifying water bodies. Data analysis techniques to detect reduced lidar return densities were evaluated for test sites in Blackhawk County, Iowa, and Beltrami County, Minnesota, to delineate contiguous areas that have few or no lidar returns. Results from this study indicated a 5-meter radius moving window with fewer than 23 returns (28 percent of the moving window) was sufficient for delineating void regions. Techniques to provide elevation values for void regions to flatten water features and to force channel flow in the downstream direction also are presented.

\section{Introduction}

Although it is well documented in the scientific literature that lidar-derived digital elevation models (DEMs) frequently have been used to generate hydrographic networks (Liu and others, 2005; Colson and others, 2006; Jones and others, 2008; Li and Wong, 2010; Medeiros and others, 2011; Petroselli, 2012; Poppenga and others, 2010, 2012, 2013), an analysis of the actual lidar return density has implications for extracting water bodies. Historically, the approach for extracting water features was to digitize water features from aerial photographs or topographic paper maps (Guptill, 1980, 1983; Marks and others, 1984; Usery, 2012). Newer production methods for generating high-resolution, high vertical accuracy lidarderived DEMs commonly are generated using interpolation methods based on triangular irregular networks (TIN). The resulting DEMs provide great detail of the land's surface form.

\footnotetext{
${ }^{1}$ Stinger Ghaffarian Technologies (SGT), Inc., contractor to the U.S. Geological Survey Earth Resources Observation and Science (EROS) Center. Work performed under USGS contract G10PC00044.
}

However, as lidar point density decreases, the TIN facets become larger in size resulting in larger, unnatural triangular artifacts in the DEM. Water features in elevation data typically are depicted as flat or continuously sloping downstream for rivers. This depiction facilitates hydrologic applications as well as cartographic representation. Elevation data containing TIN artifacts, however, will adversely affect flow routing over water features for hydrologic applications as well as cartographic maps based on shaded relief or contours. The TIN artifacts should be addressed in the DEM before further hydrologic analysis.

Lidar return density can be used as a metric to discriminate void regions from nonvoid regions in the point cloud data. Several approaches have been used to map various types of water features from lidar. Most approaches use some form of point density analysis with a threshold to discern land returns from non-land returns. Thiessen polygons can be created for the lidar return points and the polygon area can be used to estimate the point density, allowing the polygons to be categorized as either land or water (Wu and others, 2009; Legleiter, 2012).

The mean shift algorithm has been used with lidar data to segment and refine land and water categories. Wu and others (2009) used this algorithm with aerial imagery to refine the water-land boundary they defined from lidar data. Lee and others (2009) used the mean shift algorithm with point density and other attributes to generate a series of land and water combinations that were resolved with ground truth information.

Intensity measurements also hold value in discerning water from land because lidar returns over water have low intensity (Höfle and others, 2009). In many cases, lidar intensity measurements are not calibrated to record intensity in a controlled manner. Höfle and Pfeifer (2007) discussed factors such as variations in terrain, sensor type, and types of objects on the land surface that can result in inconsistent intensity values for similar objects and present techniques to correct intensity values. Brzank and Heipke (2006) also noted that intensity values can be "noisy" and affected by the type of instrument used. Höfle and others (2009) improved their approach by modeling new points as water in the void regions. By having sets of water returns (real and modeled) and returns

${ }^{2}$ U.S. Geological Survey. 
over the land surface, they used techniques to partition water and non-water features.

Brzank and Heipke (2006) classified lidar returns as water and land though they did not explicitly map water regions. Their fuzzy set classification approach used six parameters, including point density, to classify points on a scan-line basis. The classification for each return was refined further using neighboring point classifications and their elevation values.

Mandlburger and Brockmann (2001) discussed the extraction of water-land boundaries from lidar and crosssection surveys derived from echo soundings. The scale of their investigation and information allowed them to constrain their analysis to the river corridor. The elevation differences between the lidar return values and the echo soundings for river channel cross sections provided a means to develop the water-land boundaries necessary for assigning elevations to the water surface. The Thiessen polygon approach described by Wu and others (2009) and Legleiter (2012) can be affected by single lidar return points. Additional steps are needed to clean the crenulations from Thiessen polygon analysis. Regionalization techniques for a given scale can reduce the effect of single points. Dikau and others (1991), Worstell (2000), and Brabyn (1996) applied a terrain classification technique using DEMs to characterize small-scale landform regions. In general, the approach evaluates proportions of terrain metric categories within a moving window rather than just the metric itself. This same approach that evaluates proportions can be applied to differentiate between void and nonvoid categories of lidar data. By defining a window appropriately sized for the desired scale, the proportion of the window containing returns can be used to delineate low albedo regions associated with water features.

In this report, a two-stage approach to detect reduced point densities, or voids, in the lidar point cloud data is described. In addition to water, other low albedo surfaces, such as asphalt roads or tar rooftops, can absorb lidar pulses causing a decrease in the lidar return density. Similarly, some features on the landscape such as water towers, grain silos, and other tall features may cast shadows that can also reduce lidar return density. Although we recognize such features exist, these types of features are small and less than the minimum area threshold we use to distinguish void regions. The voids analysis is accomplished using a raster-based focal neighborhood analysis (moving window analysis) that is common to many geographic information system (GIS) software packages. In addition, an approach is presented for assigning constant elevation values to void regions covering lakes/ponds and for assigning river channel elevation values that decrease in the downstream direction.

Detecting water features directly from lidar point cloud data can improve delineation of water features. This is important for wetland water body identification that is needed for flood mitigation (Huang and others, 2011), improving riparian channel environments (Hutton and Brazier, 2012), and defining storm water detention basins (Wang and Yu, 2012).

\section{Study Area}

The methods for detecting voids in lidar data were tested in Iowa and Minnesota. The Iowa site is in Blackhawk County along the Cedar River and is located in the Eastern Iowa and Minnesota Drift Plains ecoregion (U.S. Environmental Protection Agency, [n.d.]) (fig. 1). The Minnesota site is located in Beltrami County along the Clearwater River and is located in the Chippewa Plains ecoregion (U.S. Environmental Protection Agency, [n.d.]) (fig. 2). In the study area, the Clearwater River flows from south to north and drains westward into the Red River of the North. The Clearwater River is part of the Red River Basin that drains into Lake Winnipeg and Hudson Bay, Canada.

\section{Data Used in the Analysis}

The lidar data used in the Iowa study area were developed by the Iowa Lidar Consortium (Iowa LiDAR Consortium, 2007) and obtained from the U.S. Geological Survey (USGS) Center for Lidar Information Coordination and Knowledge (CLICK) (Stoker and others, 2006). In this study area, the lidar data were collected in 2008 using a Leica ALS50 sensor and include point cloud data and approximately 1-meter (m) horizontal resolution DEM raster data. The vertical accuracy at the 95-percent confidence level of the lidar DEM was reported by the vendor to be 36.26 centimeters on open bare earth terrain, and 75.52 centimeters in vegetative areas.

The lidar data used in the Minnesota study area were developed by the International Water Institute Red River Basin Lidar Mapping Initiative (International Water Institute, 2010a, 2010b) and obtained from the USGS CLICK (Stoker and others, 2006). The lidar data were collected using a Leica sensor ALS50-II MPiA system at 8,000 feet $(2,438 \mathrm{~m})$ above mean terrain between April 25, 2009, and May 17, 2009. The overall vertical accuracy assessment at the 95-percent confidence level based on 118 points was plus or minus 25.5 centimeters as determined by the vendor (International Water Institute, 2010b).

\section{Lidar Point Density Analysis}

A point density analysis of lidar returns can provide the base information needed to spatially delineate void regions. To facilitate data processing, all lidar returns are rasterized at 1-m resolution (Lee and others, 2008). The rasterized data are coded with a value of one to represent a lidar return or a value of zero to represent a void. Additionally, the bare earth return $z$-values are rasterized at $1-\mathrm{m}$ resolution.

A focal neighborhood analysis of the rasterized data is used to assess the lidar return density. The 5 -cell radius 

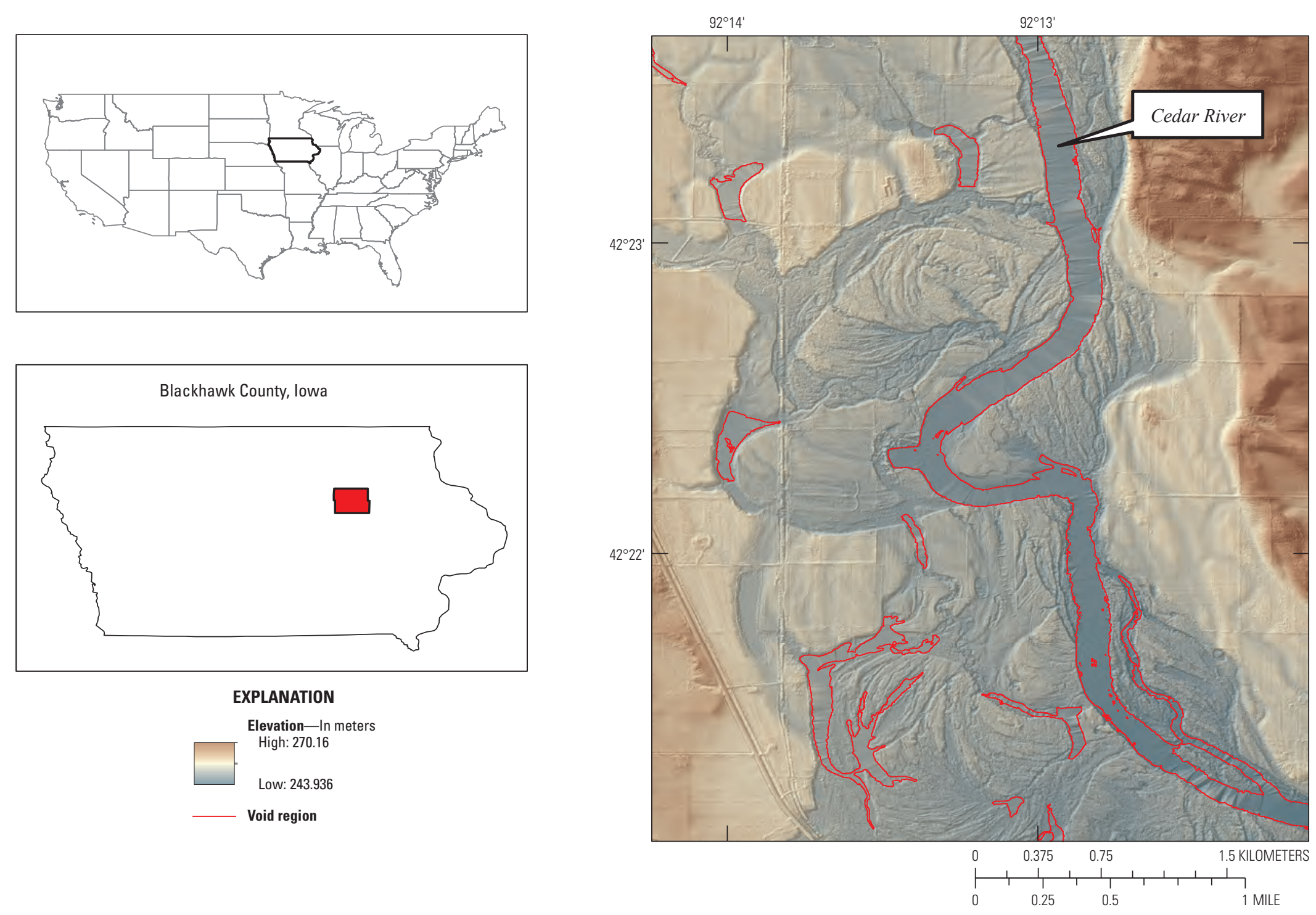

Figure 1. Cedar River area in Blackhawk County, lowa.



EXPLANATION

Elevation-In meters

High: 270.16

Low: 243.93

Void region 

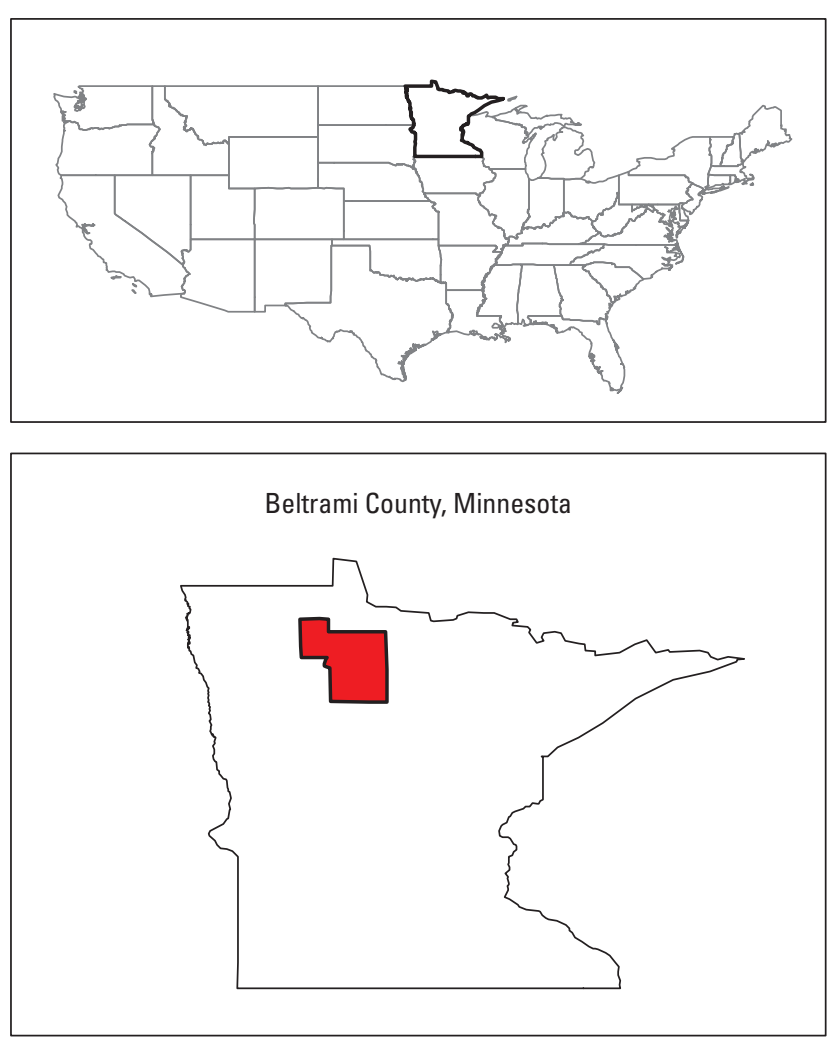

\section{EXPLANATION}

Elevation-In meters

High: 457.5

Low: 404.06

Void region

Figure 2. Clearwater River area in Beltrami County, Minnesota

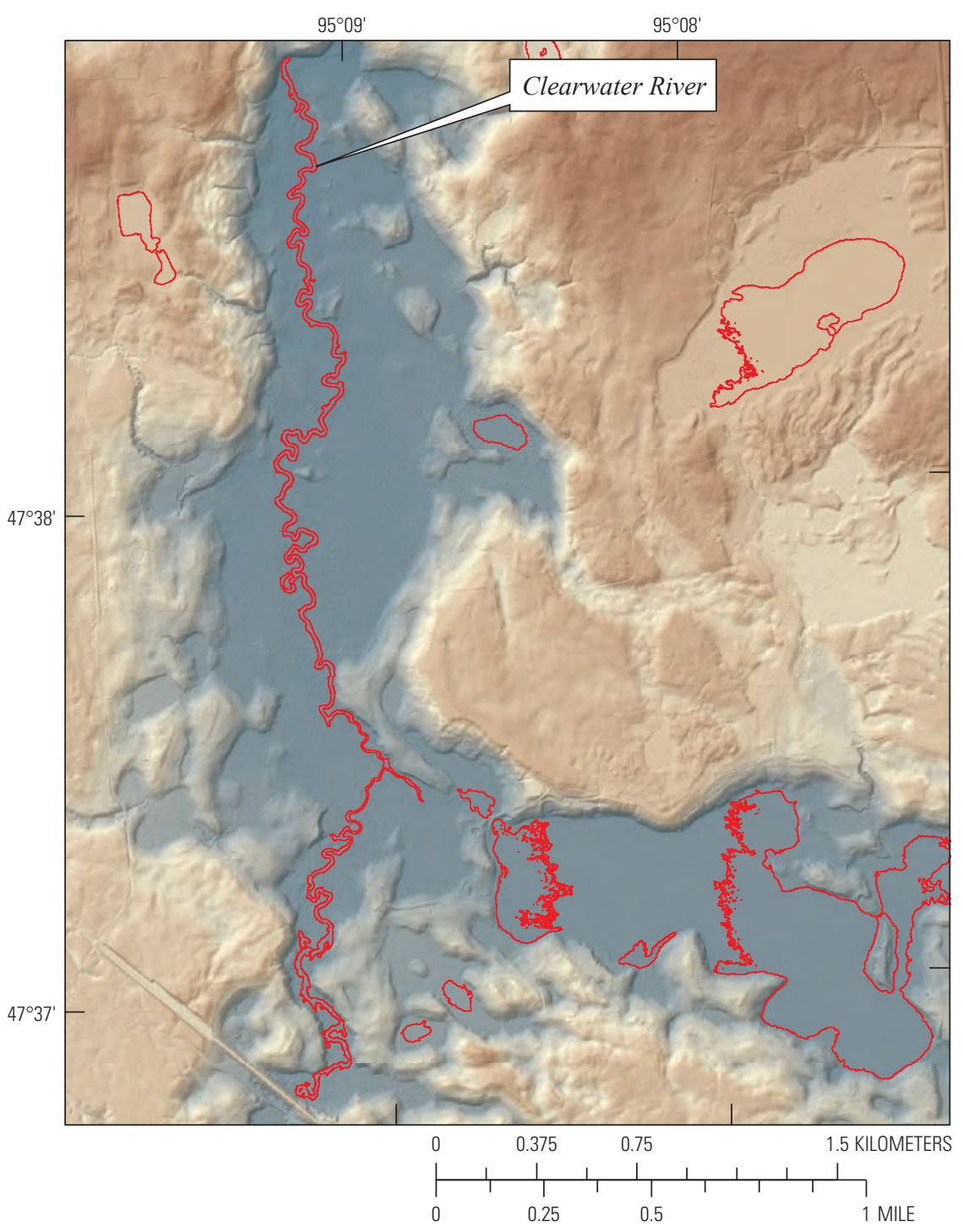




(meter) circular moving window has an area totaling 81 cells. This size of moving window balances generalizing the edge of the void regions and retaining detail along the void edges. By summing the rasterized returns within the 81-cell moving window, the proportion of the window with return values can be determined. For example, if all 81 cells contained returns, the return density would be high (100 percent). If only 20 cells contained returns, the density would be low ( 25 percent). Therefore, a threshold can be used to differentiate void regions (low return density) from nonvoid regions (high return density). A visual assessment of different threshold values was used to select one that agreed well with the shorelines.

The overall, first-stage approach is illustrated in figure 3. All lidar returns are first rasterized as shown in figure $3 \mathrm{~A}$ as white (ones). Areas in figure $3 A$ where there are no lidar returns (voids) show up as black (zeroes). The neighborhood analysis, or focal sum, that counts the number of returns in the moving window analysis is used to measure point density (fig. 3B). A threshold value was selected to distinguish high density areas (sums near 81) from low density areas (sums near zero). The output of the threshold analyses is shown in figure $3 C$. Small isolated zones less than 4,047 square meters (1 acre) are removed so that only zones of substantial size remain (fig. $3 D$ ). These zones will be used to delineate the final void regions. The area limit of 4,047 square meters that was used to exclude the small regions in figure $3 C$ was a project-imposed minimum mapping unit limit, and it is likely that smaller areas could be included if necessary.

The second stage is a refinement step used to exclude possible artifacts. This is done by defining void regions using a very low threshold value and then using these regions to select the regions derived using a higher value that spatially intersects with them. This two-stage approach helps prevent irregularly shaped artifacts like the one depicted in figure 4 . The dark blue color in figure 4 represents the void regions defined using the very low threshold value. The red color in figure 4 represents void regions defined using a higher threshold value. The cyancolored polygon is the final void, which is the outline of the red void that spatially intersects with a blue void.

\section{Elevation Assignment for Void Regions}

Lidar data commonly are used to portray a continuous surface such as bare earth elevation. Data voids in the lidar point cloud disrupt the surface, forcing users to fill in voids with data values derived from TIN interpolation techniques. An assessment of lidar elevation values around the outer edge of the void region polygon can provide estimated elevation values for the interior area of the void region.
Water bodies on the landscape exist in a wide variety of shapes, sizes, and combinations. For the purposes of this research, water bodies are categorized as either a simple polygon (lake or pond shape) or an elongated river channel segment. The category is then used to select the method to assign new elevation values for each void region. The void region area, the area to perimeter ratio, and the circular ratio (Miller, 1953) (4x $\pi \times$ area/perimeter ${ }^{2}$ ) criteria are used to categorize each polygon as simple or elongated. The elongated voids are processed to estimate the slope and apply elevations that decrease in the downstream direction. Void regions with minimal elevation changes can create unreliable slope values. These voids are treated as non-elongated voids and are modified using a single value.

The assignment of a new elevation value for a simple polygon (lake/pond) is determined by sampling a buffer region around the void. The buffer region is used to analyze the bare earth lidar returns around the edge and the interior of the void. The new elevation for the void is calculated by subtracting one standard deviation from the mean elevation. This calculation produced the best result and reduced the chance that a single, extremely low elevation would introduce an artifact into the data. The mean and minimum elevations were considered but sometimes resulted in introducing new artifacts where the water surface was raised above the neighboring terrain or substantially lower than the surrounding terrain.

New elevation values are assigned to elongated void regions by applying decreasing elevation values in the downstream direction across the void. By visually assessing the data, a distance of 1,000 $\mathrm{m}$ was selected as the length threshold to differentiate elongated features that were part of a river channel. This length was chosen as a guideline to select which elongated polygons should be tested to see if elevations along the edge have a slope in the downstream direction. Each of the elongated regions exceeding 1,000 $\mathrm{m}$ was buffered and segmented into equal length units to generalize elevations at equal intervals along the void. The units are used to sample the bare earth lidar return elevation values and the mean distance the segment is from the most downstream point of the region. A least squares fit is used to determine if there is a slope across the segments. Using the slope, new elevation values that increase with the slope are applied continuously as a function of the distance upstream in an automated manner for each void. The new distance weighted elevation values are used if the relief is above the minimum threshold. If the overall change in elevation is less than the minimum threshold, the entire elongated zone is treated as a simple lake/pond polygon using a single elevation value to minimize the risk of applying the slope in the wrong direction. The overall data processing flow is illustrated in figure 5. 



Figure 3. Segmentation of lidar returns into regions of voids and nonvoids. $A$, illustrates all lidar rasterized returns in white and voids in black. $B$, illustrates focal neighborhood sum of graphic $A$ where values range from 0 to 81 . $C$, shows the application of a threshold of 23 cells to graphic $B$.

$D$, is a refinement of graphic $C$ where small isolated areas less than the minimum mapping unit have been removed. 


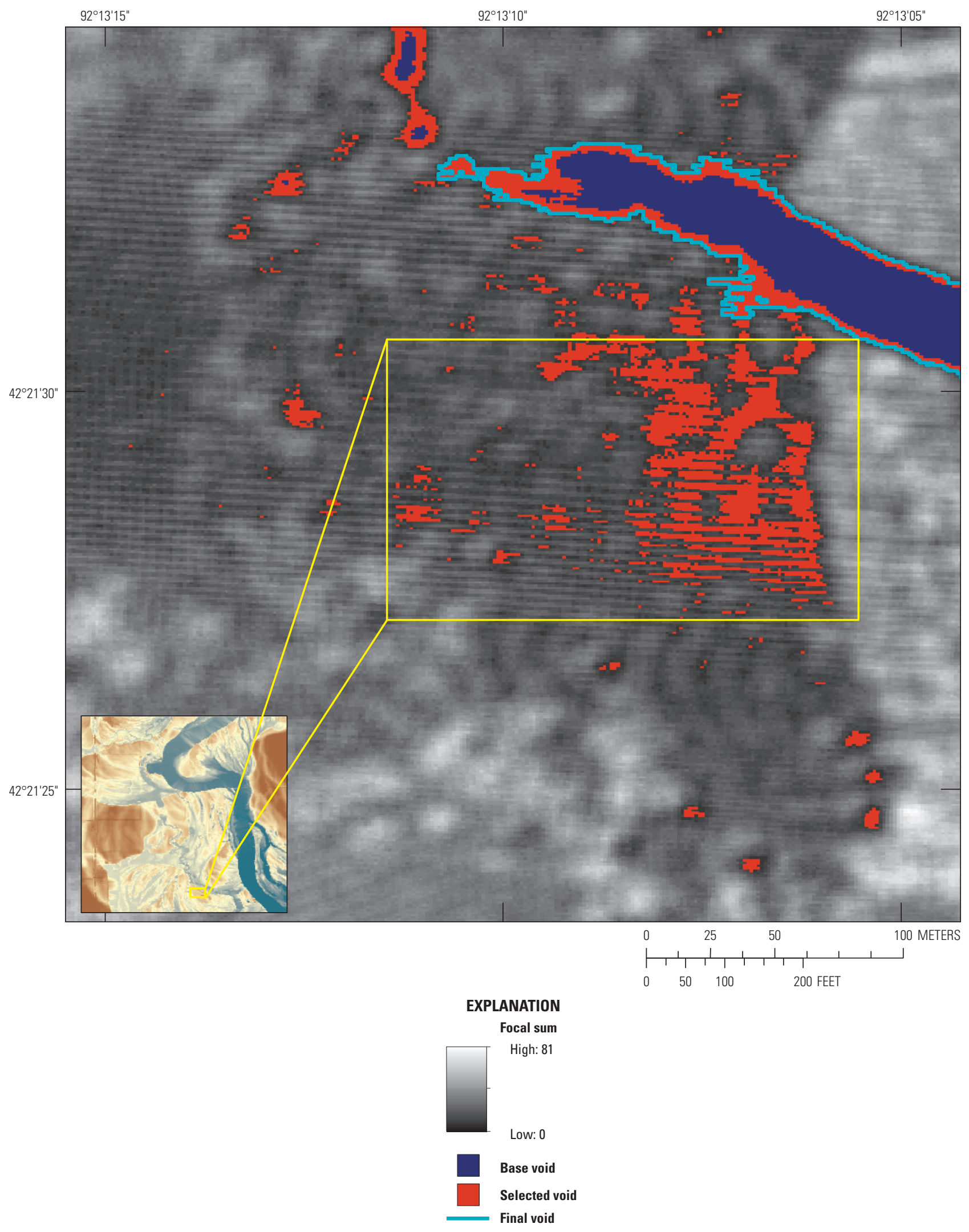

Figure 4. Example of artifacts (highlighted in the yellow box) when a single threshold is used to discriminate voids. The cyan-colored polygon represents the void delineated using the two-stage approach. 
Void delineation

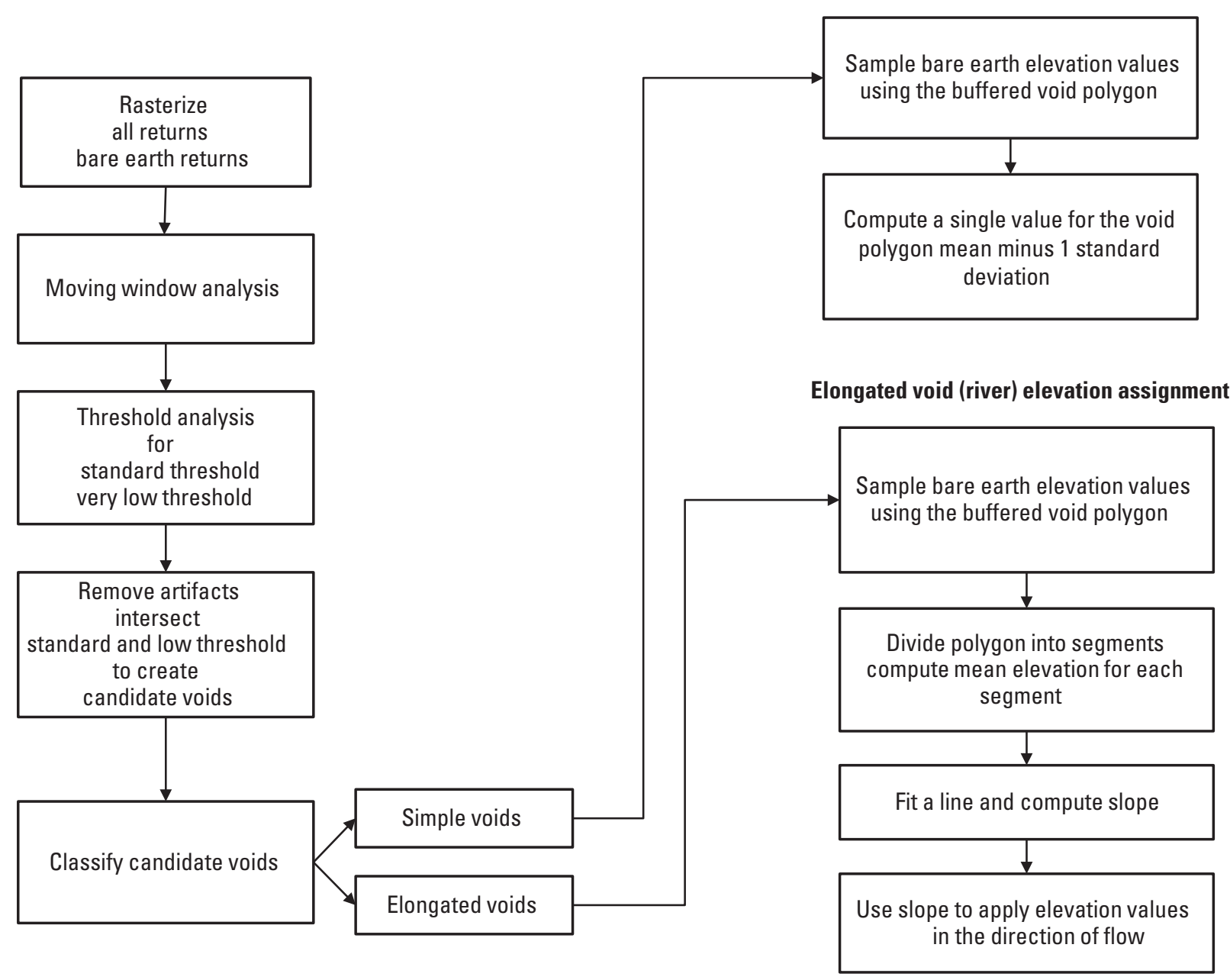

Figure 5. Overall data processing flow chart.

\section{Lidar Return Density Variability of Void Regions}

Lidar return density varied greatly for the study sites. All lidar returns (white) for the Iowa study site are depicted in figure $6 A$. The spatial density is calculated by summing the number of returns using the focal neighborhood analysis (fig. 6B) where the light grey in the focal sum analysis represents high point return density and darker grey represents lower return density. Establishing a threshold makes it possible to differentiate void regions from nonvoid regions. After experimenting with various thresholds, it was determined that the low threshold of 10 cells (12 percent of the moving window) identified seed regions that are used to spatially select regions based on the second threshold of 23 cells ( 28 percent of the moving window). The final regions are then uniquely labeled to prepare for assigning new elevation values to the void regions (fig. 7).

\section{Assigning New Elevation Values in Rivers, Lakes, and Ponds}

The bare earth data used to compute mean minus one standard deviation were sampled from the void region buffered by $3 \mathrm{~m}$. The $3-\mathrm{m}$ buffer was sufficient for sampling elevation returns along the edge of the void/land interface. The aerial imagery in figure $8 A$ shows an example water body, original lidar-derived elevation raster (fig. $8 B$ ), and modified lidar-derived elevation raster (fig. $8 C$ ) for one of the void regions. Triangular irregular network artifacts can be seen in the interior part of the void region (outlined in black) in figure $8 B$. These artifacts are produced because of the lack of lidar returns over the water bodies during the lidar DEM generation. The modified void region, depicted in figure $8 C$, is represented with a single elevation value and no longer has any TIN artifacts. 


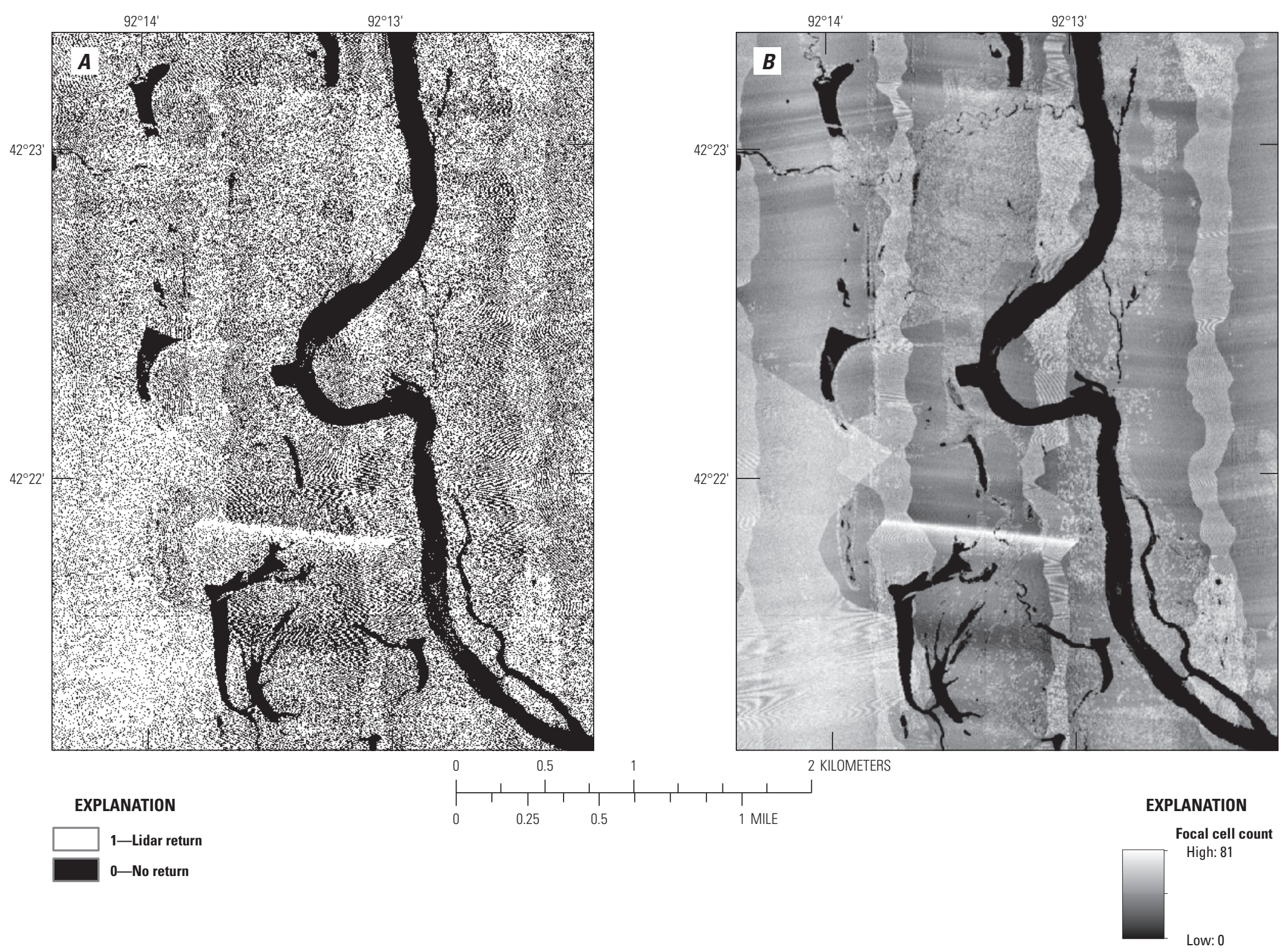

Figure 6. Moving window analysis of rasterized lidar data for the lowa study site. Lidar returns are depicted in white $A$ and the focal neighborhood sum of the returns is depicted in $B$. Also note the irregular vertical stripes in the image where the lidar acquisition flight lines overlap. Since the void analysis focuses on low point densities from point drop-off, the high density point returns in the overlap area do not affect the analysis. 




Figure 7. Void regions for the Blackhawk County, lowa, site. 

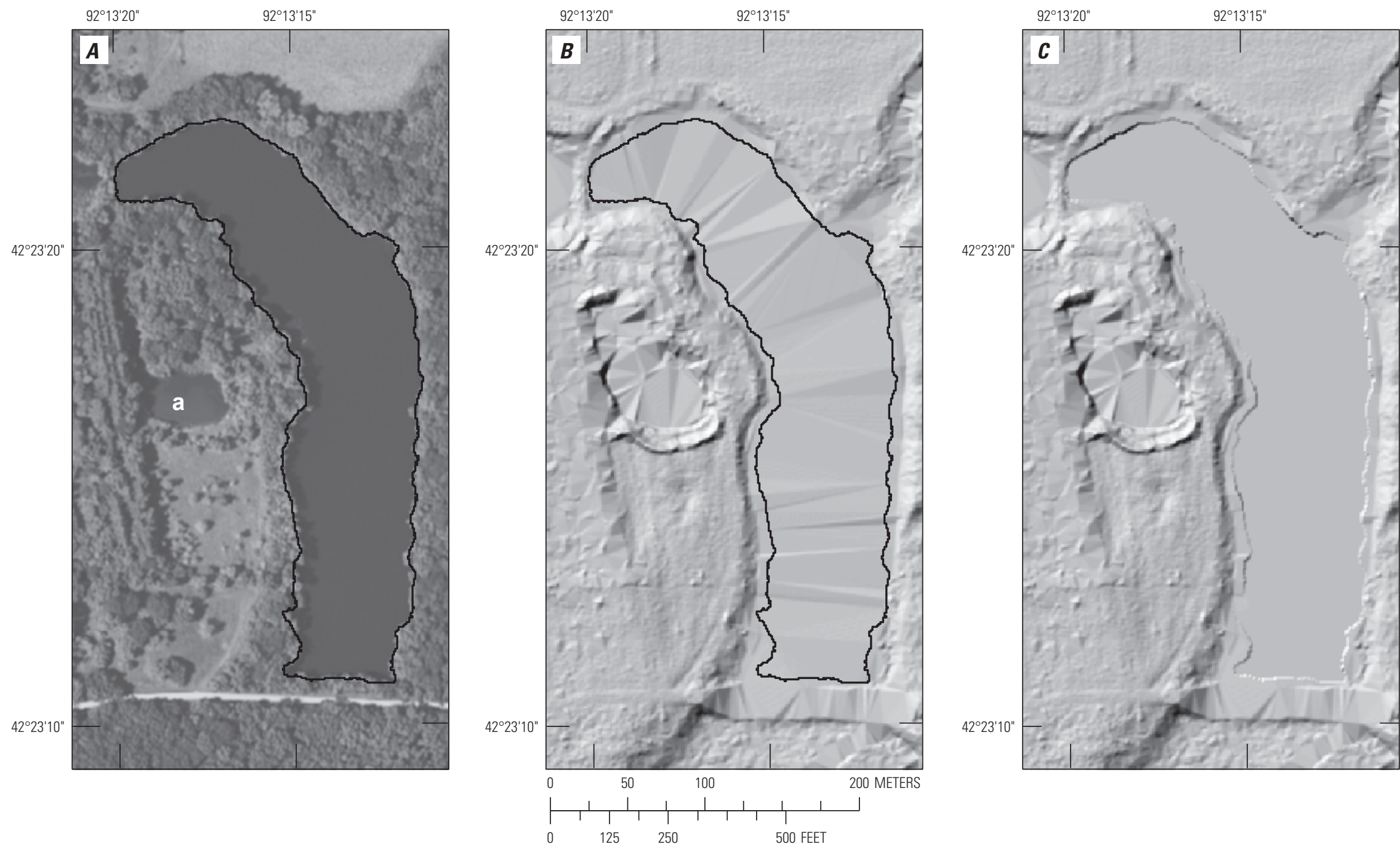

EXPLANATION

Figure 8. Example of a simple void region over a water feature. $A$, Aerial imagery of water body with black polygon outlines representing void regions. $B$, TIN artifacts present in the void regions. $C$, Modified void region using a new single elevation value. Note the small water body labeled "a" in the middle left of graphic $A$ is not flattened in graphic $C$. Though this area is a void region over a water body, the area of this polygon is less than 4,047 square meters and was excluded from the analysis. 
A void region with a substantial number of interior returns designated as nonvoid is shown in figure 9. These miscellaneous nonvoid areas may be from waterfowl, materials floating on the water, or wave action, but it is not uncommon to see some small interior polygons within the void region. Another void region with interior lidar returns is depicted in figure 10. In this case, the returns are from an island in the middle of the water body.

Examining the imagery in figures 8,9 , and 10 more closely, the black polygon lines have crenulations that closely follow the edges of the treetops that appear to overhang the water bodies. This overhang effect is from using all lidar returns to define void regions rather than just the bare earth returns. Bare earth returns can be sparse in areas of dense vegetation. If bare earth returns were used in these study sites, the void regions might extend inland further than the water boundary. In urban areas, lidar returns for buildings are typically not classified as bare earth, which causes voids the same way water bodies cause voids. However, simply filling these voids with a single value could introduce more pronounced artifacts than the original TIN artifacts that may be present using these methods.

Elongated voids on river channels are treated differently from non-elongated lakes and ponds. Void regions with an area to perimeter ratio less than 20 and circular ratio less than 0.1 were categorized as an elongated polygon. Since river channels are sloping, a single elevation value could introduce substantial edge artifacts, particularly at the upper and lower ends of the void. Decreasing elevation values are applied in the direction of the channel slope using an estimated slope from the sampled bare earth elevations. Each elongated void exceeding 1,000 $\mathrm{m}$ in length is buffered $3 \mathrm{~m}$ and segmented into 50-m units. A fitted line is used to determine a slope using the average elevations of the units that make up the void. The slope value is used to automatically apply decreasing elevation values in the downstream direction. In instances where the overall void elevation change was less than $0.5 \mathrm{~m}$, we treated the elongated polygon as a non-elongated lake because we could not reliably determine a slope in the correct downstream direction. The original elevation data for a portion of the Cedar River in Iowa are depicted in figure $11 A$ and the modified elevation data are shown in figure $11 B$. This elongated void was processed as a river channel with a sloping surface in the downstream direction (top to bottom in fig. 11). The modified channel in figure $11 B$ is satisfactory with no noticeable anomalies. A portion of the Clearwater River in Minnesota is depicted in figure 12. Unlike the channel in figure 11, this channel is narrower and appears to rise above the shoreline of the river bank, resulting in an undesirable modification to the river channel elevations.

\section{Limitations and Considerations}

Not all voids in lidar point cloud data are indicators of water. For example, low albedo surfaces, such as asphalt roads or tar rooftops, also can result in reduced lidar point densities. Additional research considerations to partition low albedo surface features from river channels and lakes/ponds could include ancillary land cover data or orthorectified aerial imagery fused with lidar-derived DEMs (Wu and others, 2009). This combination would improve identification of such clustered rooftop or asphalt features typical of urban areas; however, imagery acquisitions should be temporally consistent with lidar data acquisitions for congruous validation.

Lidar point classification and lidar signal intensity metrics were considered but not incorporated into the techniques described in this report. Among the disparate lidar point cloud data available in CLICK (Stoker and others, 2006), the methods used for assigning a point classification scheme, whether by manual or automated editing, vary widely and remain unreliable for water body identification in part because of the lack of lidar returns over water bodies. Additionally, because airborne laser scanning (ALS) signal intensity is not calibrated over water and is not multispectrally based, it is not a reliable metric to exclusively define river channels or lakes/ponds (Höfle and Pfeifer, 2007). Variations in scan geometry do not allow for a homogeneous sampling of the whole area, which results in under-sampling (gaps) and over-sampling (overlapping footprints). Thus, signal intensity has to be corrected for the effects of topography and flying altitude (Höfle and Pfeifer, 2007; Höfle and others, 2009).

The 23-cell threshold was adequate for differentiating void regions. Ideally, if lidar return dropouts always coincided with the shoreline, a threshold near 50 percent might produce the best result; however, shallow water areas may produce returns that could shift the line out into the water. Relaxing the threshold with a lower value shifts the boundary back toward the true shoreline. The two-stage approach for delineating void regions minimizes the chance of mapping poorly defined voids that have irregular boundaries such as swamp marsh or areas where an entire scan-line has an unusually low density. An attempt to use a single stage delineation of voids, followed by automated artifact identification, was not reliable and required too much manual editing. The yellow box in figure 4 shows an example artifact that can be classified as a void to be fixed. In this case, it appears that the lower point density follows the direction of the scan-lines and probably was due to an increase in the velocity of the aircraft. If only the higher threshold was used to map the void, the linear artifact in the yellow box would be included and would result in applying elevation edits inappropriately. Using the two-stage approach, 

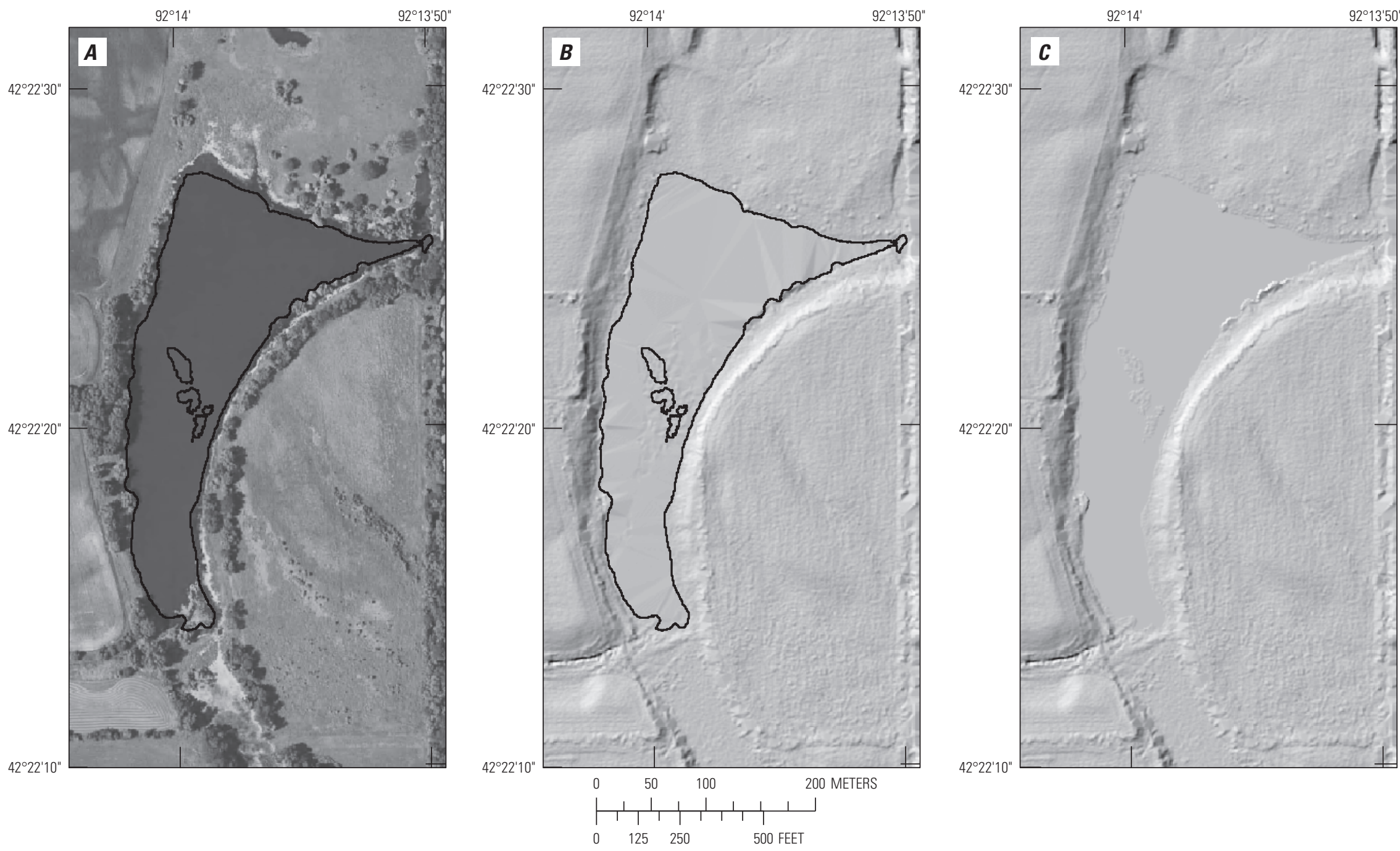

EXPLANATION

Figure 9. Example of a void region with interior polygons designated as nonvoid. $A$, Aerial imagery of water body with polygon representing the void region. $B$, Void region with interior polygons shown on the unmodified lidar elevation data. $C$, Modified void region using a new single elevation value. 

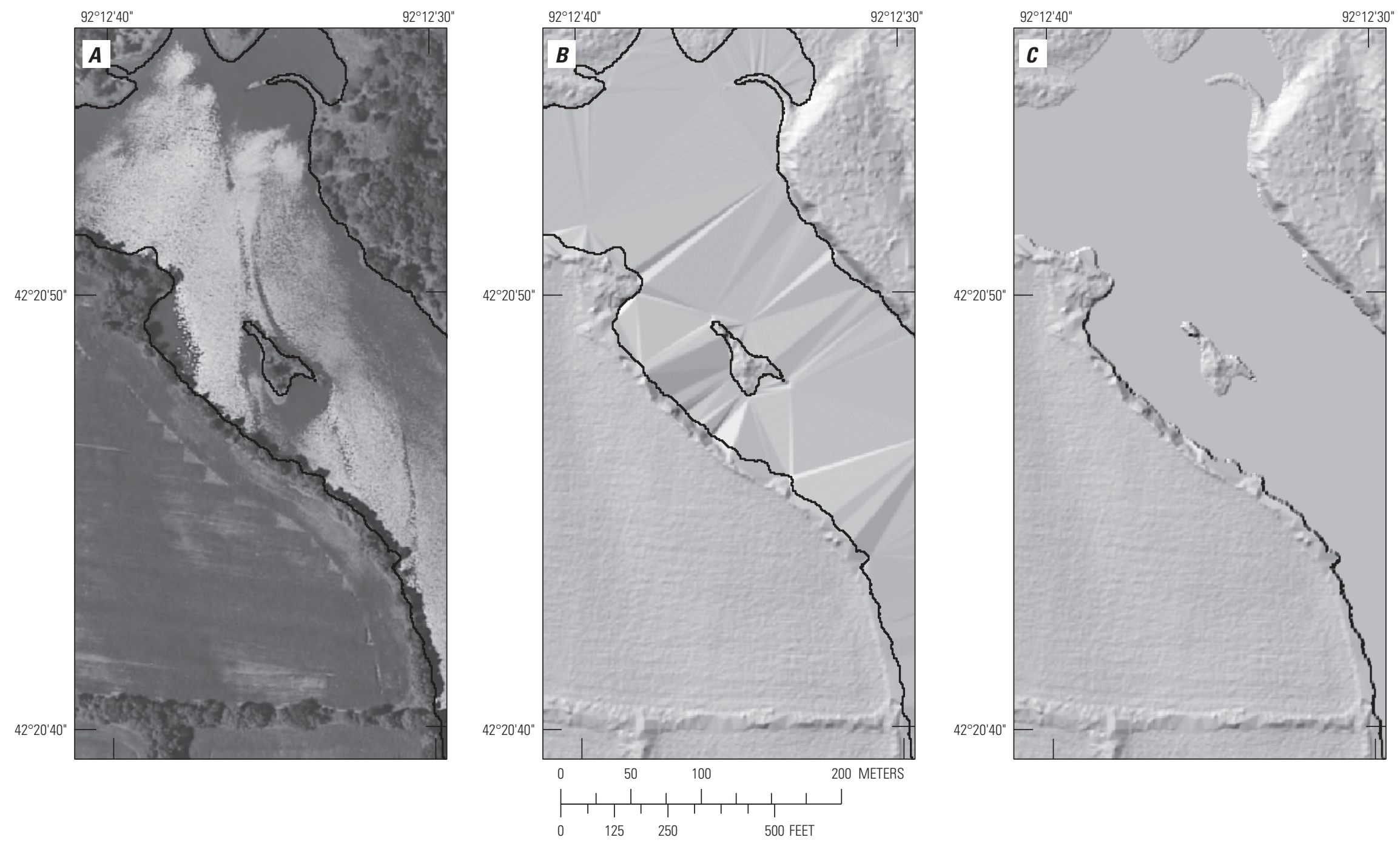

\section{EXPLANATION}

Figure 10. Example void region with an interior island. $A$, Aerial imagery of water body with polygon representing the void region. $B$, TIN artifacts present in the void region. $C$, Modified void region using a new single elevation value. 
$92^{\circ} 13^{\prime}$

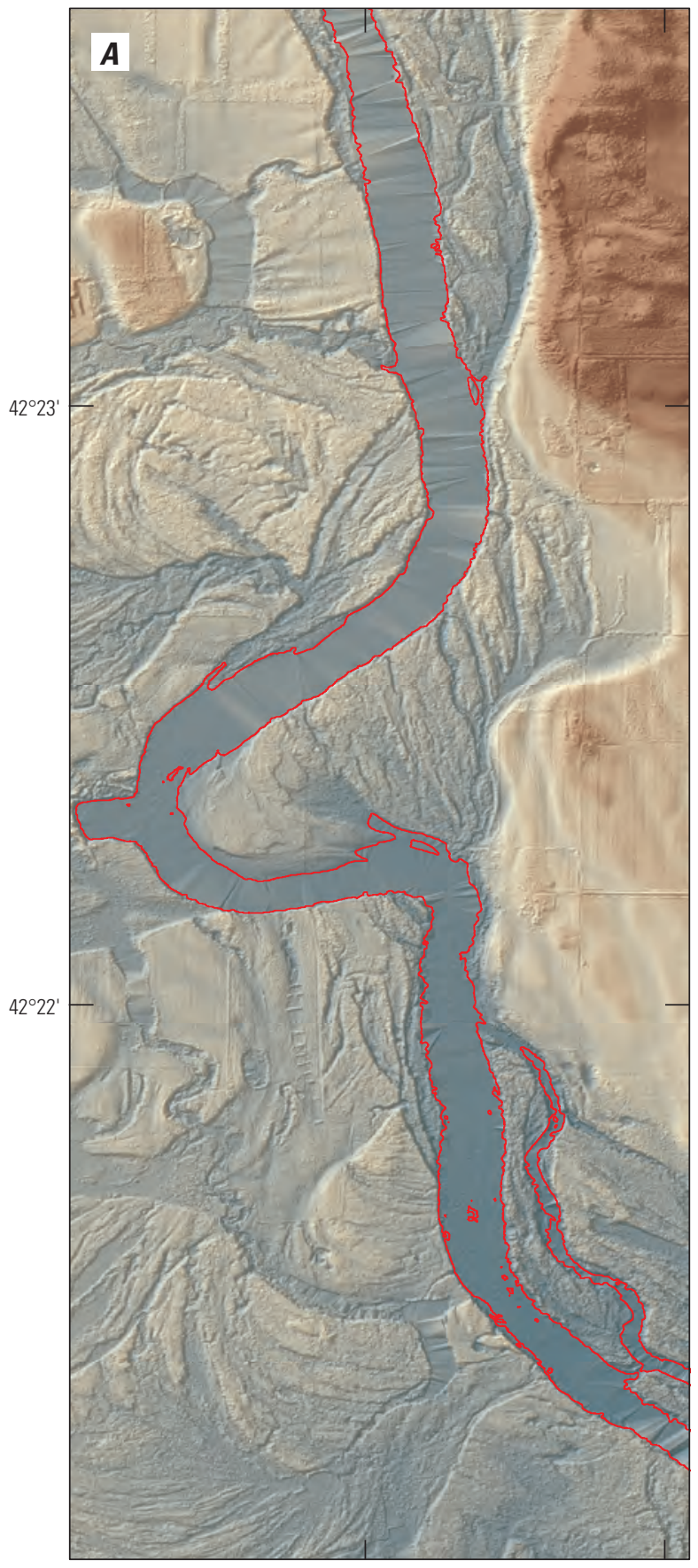

$0 \quad 250 \quad 500$

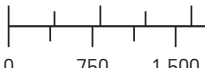

EXPLANATION

B

$42^{\circ} 23$

$92^{\circ} 13^{\prime}$

$92^{\circ} 1230^{\prime \prime}$

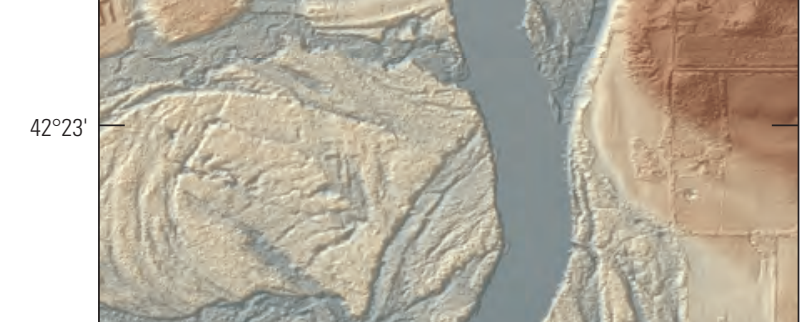




Figure 12. Comparison of the original, $A$, and the modified, $B$, river channels located in Beltrami County, Minnesota. Note that the elevation of the river channel is higher than the surrounding shoreline. 
the dark blue regions in figure 4 are established first using the base threshold. These regions are then used to spatially select regions derived using the higher threshold. The final void in this area is outlined in cyan and excludes the area affected by the artifact. Although the example voids presented correspond to water bodies, urban features such as tar rooftops, asphalt roads, and other low albedo surfaces also likely would be delineated using this approach if they were present in this study site.

Delineating river channel voids is complex and challenging. Small voids (less than 1,000 m) in river channels can be treated as simple ponds and filled with a single value. However, applying a single value to river channel void regions greater than $1,000 \mathrm{~m}$ in length may cause cliff-like artifacts at the upper and lower end of each void. Applying a slope to the elevation values may be sufficient for reducing these artifacts, but the slope values may introduce problems where the elevations in the river channel rise above the surrounding terrain as shown in figure 12, and is an unacceptable modification to the elevation data. Tyler and Greenlee (2012) used an inverse distance weighted approach for applying sloping elevations in river channels that might be better suited for these situations.

The values used for thresholds, areal, and distance limits used in this study were obtained empirically. The quality of the lidar data, point spacing, landscape features, and conditions during data collection can affect the values used for these thresholds. The use of these methods at other locations with data acquired using different specifications will likely require different thresholds to obtain suitable results.

\section{Summary}

Most airborne topographic lidar systems operate within the near-infrared spectrum. Laser pulses from these systems commonly are absorbed by water, resulting in reduced point densities or void regions over water bodies. These data voids have value in that they correspond to water features on the landscape. In this report, we illustrate a two-stage void analysis approach to detect reduced lidar point densities, or void regions, in study sites in Iowa and Minnesota. Data for parts of the Cedar River in Blackhawk County, Iowa, and Clearwater River in Beltrami County, Minnesota, were tested using a focal neighborhood analysis, or a moving window analysis, to detect reductions in lidar point densities. A low point density threshold was used to identify void regions that will act as seeds for a second point density analysis that uses a higher point density threshold. This approach does not directly address issues with voids caused by shadows from landscape features such as a water tower or grain silos. Low albedo surfaces such as asphalt roads or tar-coated building rooftops were not addressed.

Two different techniques were used to apply elevation values to void regions to discriminate between simple polygons (lakes/ponds) and more complex elongated polygons (river channels). Point density analyses of lidar returns were satisfactory for detecting void regions for simple polygons (lakes/ponds); however, for elongated void regions, a slope was estimated, and elevation values were assigned in the downstream direction of flow.

Efficient and cost-effective delineation of water features from high-resolution, high-vertical accuracy lidar-derived DEMs is challenging. Because void regions in lidar point cloud data can introduce TIN artifacts in water bodies in lidar-derived DEMs, additional efforts are needed to not only correct, or flatten, the DEM, but also to delineate the water bodies. Point density analyses of lidar returns to define void regions may provide a viable solution for identifying and flattening hydrologic features. These void regions provide a promising framework to flatten water body elevation values that otherwise would contain TIN artifacts. Most importantly, the void regions provide important benefits for water body delineation and could play a role in efforts to update surfacewater features.

\section{Acknowledgments}

The authors wish to thank Dean Gesch, Research Physical Scientist and Roger Auch, Research Geographer, U.S. Geological Survey, Earth Resources Observation and Science (EROS) Center, for their scientific and technical review of this manuscript.

\section{References Cited}

Brabyn, L., 1996, Landscape classification using GIS and national digital databases: Landscape Research, v. 21, no. 3, p. 277-300. [Also available at http://dx.doi.org/ 10.1080/01426399608706493.]

Brzank, A., and Heipke, C., 2006, Classification of lidar data into water and land points in coastal areas, in Forstner, W., and Steffen, R., eds., Symposium of ISPRS Commission III Photogrammetric Computer Vision PCV ‘ 06, Bonn, Germany, 20-22 September 2006, v. XXXVI, pt. 3: Lemmer, The Netherlands, International Society for Photogrammetry and Remote Sensing, p. 1-6. [Also available at http://www. isprs.org/proceedings/XXXVI/part3/singlepapers/P_19. $p d f$.]

Colson, T.P., Gregory, J.D., Mitasova, H., and Nelson, S.A.C., 2006, Comparison of stream extraction models using LIDAR DEMs, in Maidment, D.R., and Grounds, J.S., eds., GIS and water resources IV-Proceedings of the American Water Resources Association 2006 Spring Specialty Conference, Houston, Tex, May 8-10, 2006: Middleburg, Va., American Water Resources Association, 1 CD-ROM. 
Dikau, R., Brabb, E.E., and Mark, R.M., 1991, Landform classification of New Mexico by computer, U.S. Geological Survey Open-File Report 96-634, 15 p., accessed June 3, 2014, at http://pubs.er.usgs.gov/publication/ ofr 91634 .

Guptill, S.C., 1980, The development and use of digital cartographic data bases, in Blaser, A., ed., Data base techniques for pictorial applications-Florence, June 20-22, 1979: Berlin, Germany, Springer-Verlag, p. 65-77.

Guptill, S.C., 1983, The role of digital cartographic data in the geosciences: Computers and Geosciences, v. 9, no. 1, p. 23-26. [Also available at $h t t p: / / d x$.doi.org/10.1016/00983004(83)90032-8.]

Höfle, B., and Pfeifer, N., 2007, Correction of laser scanning intensity data - Data and model-driven approaches, ISPRS Journal of Photogrammetry and Remote Sensing, v. 62, no. 6, p. 415-433, accessed June 3, 2014, at $h t t p: / / d x . d o i$. org/10.1016/j.isprsjprs.2007.05.008.

Höfle, B., Vetter, M., Pfeifer, N., Mandlburger, G., and Stötter, J., 2009, Water surface mapping from airborne laser scanning using signal intensity and elevation data: Earth Surface Processes and Landforms, v. 34, no. 12, p. 16351649, accessed June 3, 2014, at http://dx.doi.org/10.1002/ esp. 1853.

Huang, S., Young, C., Feng, M., Heidemann, K., Cushing, M., Mushet, D.M., and Liu, S., 2011, Demonstration of a conceptual model for using LiDAR to improve the estimation of floodwater mitigation potential of Prairie Pothole Region wetlands: Journal of Hydrology, v. 405, no. 3-4, p. 417426, accessed June 3, 2014, at http://dx.doi.org/10.1016/j. jhydrol.2011.05.040.

Hutton, C., and Brazier, R., 2012, Quantifying riparian zone structure from airborne lidar: Vegetation filtering, anisotropic interpolation, and uncertainty propagation: Journal of Hydrology, v. 442-443, p. 36-45, accessed June 3, 2014, at http://dx.doi.org/10.1016/j.jhydrol.2012.03.043.

International Water Institute, 2010a, Red River Basin LiDAR Mapping Initiative, Block J LiDAR 3rd Party Quality Assessment Report: Fargo, N.D., International Water Institute, $71 \mathrm{p}$. [Also available at $h t t p: / / w w w . i w i n s t . o r g / l i d a r /$ forms/QC_Report_Block_J.pdf.]

International Water Institute, 2010b, Red River Basin mapping initiative 2008-2010: accessed August 13, 2013, at http:// gis.rrbdin.org/RRBMI_Metadata.HTML.

Iowa LiDAR Consortium, [2007], The Iowa LiDAR Mapping Project-LAS and ASCII files: accessed July 30, 2012, at http://geotree2.geog.uni.edu/Lidar/iowa_lidar_metadata. html.
Jones, K.L., Poole, G.C., O'Daniel, S.J., Mertes, L.A.K., and Stanford, J.A., 2008, Surface hydrology of low-relief landscapes: Assessing surface water flow impedance using lidar-derived digital elevation models: Remote Sensing of Environment, v. 112, no. 11, p. 4148-4158, accessed June 3, 2014, at http://dx.doi.org/10.1016/j.rse.2008.01.024.

Lee, H. L., Lee, K., and Lee, S., 2008, Fusion of lidar and imagery for reliable building extraction: Photogrammetric Engineering and Remote Sensing, v. 74, no. 2, p. 215-225, accessed June 3, 2014, at http://dx.doi.org/ 10.14358/ PERS.74.2.215.

Lee, I.-C., Wu, B., and Li, R., 2009, Shoreline extraction from the integration of lidar point cloud data and aerial orthophotos using mean shift segmentation, in Reflection of the past, vision for the future-ASPRS 2009 Annual ConferenceMarch 9-13, 2009: Baltimore, Md., American Society for Photogrammetry and Remote Sensing, 1 CD-ROM.

Legleiter, C.J., 2012, Remote measurement of river morphology via fusion of lidar topography and spectrally based bathymetry: Earth Surface Processes and Landforms, v. 37, no. 5, p. 499-518, accessed June 3, 2014, at http://dx.doi. org/ 10.1002/esp.2262.

Li, J., and Wong, D.W.S., 2010, Effects of DEM sources on hydrologic applications: Computers, Environment and Urban Systems, v. 34, no. 3, p. 251-261, accessed June 3, 2014, at $h t t p: / / d x$.doi.org/10.1016/j. compenvurbsys.2009.11.002.

Liu, X., Peterson, J., and Zhang, Z., 2005, High-resolution DEM generated from LiDAR data for water resource management, in Zerger, A., and Argent, R.M., eds., MODSIM05-International Congress on Modelling and Simulation-Advances and applications for management and decision making, Melbourne, 12-15 December-Proceedings: Canberra, Australia, Modelling and Simulation Society of Australia and New Zealand, p. 1402-1408.

Marks, D., Dozier, J., and Frew, J., 1984, Automated basin delineation from digital elevation data: Geo-processing, v. 2, no. 3, p. 299-311.

Mandlburger, G., and Brockmann, H., 2001, Modelling a watercourse DTM based on airborne laser-scanner dataUsing the example of the River Oder along the German/ Polish Border, in Torlegård, E. and Nelson, J., eds., Workshop on Airborne Laserscanning and Interferometric SAR for Detailed Digital Terrain Models, Official Publication No. 40: Frankfurt, Germany, European Organization for Experimental Photogrammetric Research, 1 CD-ROM. [Also available at http://bono.hostireland.com/ eurosdr/ publications/40.pdf.] 
Medeiros, S.C., Ali, T., Hagen, S.C., and Raiford, J.P., 2011, Development of a seamless topographic / bathymetric digital terrain model for Tampa Bay, Florida: Photogrammetric Engineering and Remote Sensing, v. 77, no. 12, p. 12491256, accessed June 3, 2014, at http://dx.doi.org/ 10.14358/ PERS.77.12.1249.

Miller, V.C., 1953, A quantitative geomorphic study of drainage basin characteristics in the Clinch Mountain area, Virginia and Tennessee: New York, Columbia University, Department of Geology, Office of Naval Research project no. 089-042, Contract N6 ONR 271-30, Technical report no. 3,30 p. plus illustrations.

Petroselli, A., 2012, LIDAR data and hydrological applications at the basin scale: GIScience and Remote Sensing, v. 49, no. 1, p. 139-162, accessed September 10, 2014, at $h t t p: / / w w w . t a n d f o n l i n e . c o m / d o i / a b s / 10.2747 / 1548$ 1603.49.1.139.

Poppenga, S.K., Gesch, D.B., and Worstell, B.B., 2013, Hydrography change detection-The usefulness of surface channels derived from LiDAR DEMS for updating mapped hydrography: Journal of the American Water Resources Association, v. 49, no. 2, p. 371-389, accessed June 3, 2014, at $h t t p: / / d x$.doi.org/10.1111/jawr.12027.

Poppenga, S.K., Worstell, B.B., Stoker, J.M., and Greenlee, S.K., 2010, Using selective drainage methods to extract continuous surface flow from 1-meter lidar-derived digital elevation data: U.S. Geological Survey Scientific Investigations Report 2010-5059, 12 p., accessed June 3, 2014, at http://pubs.er.usgs.gov/publication/ofr20105059.

Poppenga, S.K., Worstell, B.B., Stoker, J.M., and Greenlee, S.K., 2012, Using selective drainage methods to hydrologically-condition and hydrologically-enforce lidar-derived surface flow, in Neale, C.M.U. and Cosh, M.H., eds., Remote sensing and hydrology — Proceedings of a symposium: International Commission on Remote Sensing of IAHS, Jackson Hole, Wyoming, USA, 27-30 September: Wallingford, UK, International Association of Hydrological Sciences, p. 329-332.

Stoker, J.M., Greenlee, S.K., Gesch, D.B., and Menig, J.C., 2006, CLICK: The New USGS Center for Lidar Information Coordination and Knowledge: Photogrammetric Engineering and Remote Sensing, v. 72, no. 6, p. 613-616. [Also available at http://www.asprs.org/a/publications/ pers/2006journal/june/highlight.pdf.]

Tyler, D.J., and Greenlee, S.K., 2012, Creation of digital contours that approach the characteristics of cartographic contours: U.S. Geological Survey Scientific Investigations Report 2012-5167, 31 p., accessed June 3, 2014, at http:// pubs.er.usgs.gov/publication/sir20125167.
Usery, E.L., 2012, The digital transition in cartographyUSGS data innovations, 1970s, in Liebenberg, E.C., and Demhardt, I.J., eds., History of cartography-International Symposium of the ICA Commission, 2010: Berlin, Germany, Springer, p. 115-128. [Also available at $h t t p: / / d x$.doi. org/ 10.1007/978-3-642-19088-9_7.]

U.S. Environmental Protection Agency, [n.d.], Level III and IV ecoregions of the continental United States, accessed June 3, 2014, at http://www.epa.gov/wed/pages/ecoregions/ level_iii_iv.htm.

Wang, L., and Yu, J., 2012, Modelling detention basins measured from high-resolution light detection and ranging data: Hydrological Processes, v. 26, no. 19, p. 2973-2984, accessed June 3, 2014, at $h t t p: / / d x$.doi.org/10.1002/ hyp.8314.

Worstell, B., 2000, Development of soil terrain (SOTER) map units using digital elevation models (DEM) and ancillary digital data: West Lafayette, Ind., Purdue University, M.S. thesis, $82 \mathrm{p}$.

Wu, H., Liu, C., Zhang, Y., and Sun, W., 2009, Water feature extraction from aerial-image fused with airborne LIDAR data, in Urban Remote Sensing Event, 2009 Joint: Piscataway, N.J., Institute of Electrical and Electronics Engineers, p. 1-7, accessed June 13, 2014, at http://dx.doi.org/ 10.1109/URS.2009.5137623.

Publishing support provided by:

Rolla Publishing Service Center

For more information concerning this publication, contact:

U.S. Geological Survey Earth Resources Observation and Science (EROS) Center

47914 252nd Street

Sioux Falls, South Dakota 57198

(605) 594-6151

Or visit the EROS Center Web site at: http://eros.usgs.gov/ 




\section{$\frac{1}{4}$}

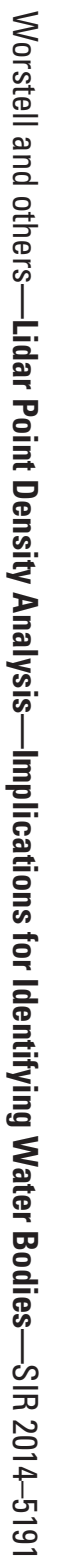

